\title{
Partai Politik, Rekrutmen Politik dan Pembentukan Dinasti Politik pada Pemilihan Kepala Daerah (Pilkada)
}

\section{Fitriyah}

Departemen Politik dan Pemerintahan, Universitas Diponegoro

\begin{abstract}
Abstrak:
Pasca terbit Putusan Mahkamah Konstitusi No.33/PUU-X1ll/2015 sebagai pembatalan larangan politik dinasti, sejumlah calon dari kerabat petahana maju dalam Pilkada 2015 dan terus berlanjut di pilkada setelahnya. Selain karena hambatan regulasi yang telah dianulir oleh Mahkamah Konstitusi, maraknya calon yang berlatar belakang dinasti terindikasi adanya masalah di partai politik dalam melaksanakan fungsi rekrutmen politik. Artikel ini berusaha menjelaskan bagaimana partai-partai politik melaksanakan proses rekrutmen politik untuk pencalonan pilkada yang ikut menyuburkan politik dinasti. Artikel ini menggunakan data dari studi literatur, hasilnya menunjukkan bahwa rekrutmen politik untuk pencalonan pilkada oleh partai politik bersifat sentralistis dan informal, serta menggunakan pertimbangan pragmatis dengan menambahkan syarat kemampuan finansial dan tingkat elektabilitas calon, sehingga lebih memberi jalan bagi calon yang berlatar belakang dinasti.
\end{abstract}

Keywords:

politik dinasti; rekrutmen politik; partai politik; pilkada serentak

\section{Pendahuluan}

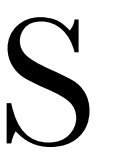

alah satu fenomena pilkada langsung di Indonesia adalah majunya calon dalam pilkada yang punya hubungan kerabat dengan kepala daerah (petahana). Model pewarisan jabatan ini terjadi di banyak daerah melalui proses politik demokrasi, fenomena ini disebut politik dinasti. Definisi politik dinasti mengacu pada satu anggota keluarga yang menempati posisi jabatan baik secara berurutan untuk posisi yang sama, atau secara bersamaan di berbagai posisi yang berbeda (Mendoza, Beja Jr, Venida, \& Yap, 2016). Dari pemberitaan di media massa bisa dideteksi jika politik dinasti di Indonesia sudah menyebar luas di daerah pasca kebijakan politik desentralisasi.

Studi yang sudah dilakukan tentang politik dinasti sebagian besar fokus pada kasus bagaimana politik dinasti di daerah terbentuk dan/atau bertahan, seperti penelitian 
mengenai dinasti Atut di Provinsi Banten (Agustino, 2010; Hidayat, 2008; Sutisna Oteng, 2000) dan dinasti Yasin Limpo di Provinsi Sulawesi Selatan (Rusnaedy \& Purwaningsih, 2018). Pada tingkat kabupaten/kota yang sudah diteliti adalah dinasti Sutrisno di Kabupaten Kediri (Bimantara \& Harsasto, 2018; Cahyaningtyas, 2018), juga secara sporadis politik dinasti di banyak daerah diangkat dalam karya ilmiah skripsi/tesis.

Fokus studi-studi tersebut menjelaskan terbentuknya politik dinasti berawal dari lahirnya orang kuat produk pilkada, lalu menyebarkan anggota keluarganya ke pos jabatan politik di legislatif dan birokrasi, dan pos-pos penting di sektor ekonomi dan masyarakat. Proses ini sebagai kaderisasi di internal keluarga petahana sebelum para anggota keluarga tersebut dicalonkan dalam pilkada.

Studi-studi tersebut menunjukkan bahwa memiliki hubungan kekerabatan dengan petahana adalah jalur cepat bagi seseorang untuk dicalonkan oleh partai politik, sehingga mengindikasikan ada masalah dalam sistem rekrutmen politik calon kepala daerah oleh partai politik. Meski studi yang sudah ada menunjukkan indikasi demikian, namun jarang yang mendiskusikan bagaimana proses rekrutmen politik dalam pencalonan kepala daerah dijalankan oleh partai politik dan mengapa calon berasal dari keluarga dinasti yang dinominasikan.

Ruang bagi munculnya politik dinasti melalui pewarisan dalam pilkada pernah dicoba ditangkal dalam norma Pasal 7 huruf (r) UU Pilkada Nomor 8 Tahun 2015 dengan cara melarang keluarga petahana maju sebagai calon kecuali telah lewat jeda satu periode masa jabatan. Namun sebelum aturan tersebut dijalankan sudah kandas karena dibatalkan oleh Mahkamah Konstutisi melalui proses judisial review. Selain karena hambatan regulasi yang telah dianulir oleh Mahkamah Konstitusi, maraknya calon yang berlatar belakang dinasti dalam Pilkada Serentak 2015, 2017, dan 2018 diduga adanya masalah di partai politik dalam melaksanakan fungsi rekrutmen politik untuk pencalonan pilkada.

Salah satu fungsi partai politik dalam pilkada adalah melakukan pencalonan. Partai politik di Indonesia dijamin hak konstitusionalnya sebagai lembaga utama yang punya otoritas dalam pencalonan pilkada, hak ini diatur dalam undang-undang pilkada dan undang-undang partai politik. Pasal 29 Ayat (1) UU No. 2 tahun 2011 tentang Partai Politik menegaskan bahwa partai politik melakukan rekrutmen terhadap warga negara Indonesia untuk menjadi bakal calon kepala daerah dan wakil kepala daerah. Kalaupun sejak UU Pilkada No. 12 Tahun 2008 akhirnya dibuka pencalonan melalui jalur perseorangan namun jalur yang ini lebih sepi peminat. Artikel ini berupaya berkontribusi menjelaskan keberadaan calon berlatar belakang dinasti dalam Pilkada Serentak 2015, 2017, dan 2018 yang tetap marak sebagai indikasi kuat adanya masalah dalam sistem perekrutan calon kepala daerah oleh partai politik.

Guna memenuhi tujuan di atas, artikel ini berangkat dari pendekatan kualitatif (Creswell, 2014: 4), dan jenis penelitian yang digunakan adalah kajian literatur (Zed, 
2008). Sumber data menggunakan data sekunder dari hasil penelitian yang dipublikasikan dan pemberitaan di media online yang dipilih secara purposif. Data yang dikumpulkan adalah yang terkait dengan politik dinasti di daerah dan rekrutmen politik untuk pencalonan pilkada oleh partai politik. Data yang sudah diperoleh kemudian dianalisis dengan metode analisis deskriptif.

\section{Rekrutmen Partai Politik: Sebuah Kajian Teoritik}

Salah satu fungsi partai politik dalam sistem politik demokrasi adalah fungsi rekrutmen politik (Norris, 2006: 89), fungsi ini merupakan fungsi khas partai politik. Bagi partai politik, calon yang dinominasikan memainkan peran penting dalam menentukan karakteristik partai politik yang bersangkutan di depan publik (Katz, 2001) bahwa rekrutmen politik menunjukkan tipologi partai. Jadi, apakah sebagai partai massa, kader, catch-all, kartel atau busines-firm dapat dilihat dari bagaimana rekrutmen politik dilakukan (Katz, 2001; Pamungkas, 2009: 37).

Adapun yang dimaksud dengan rekrutmen politik adalah proses oleh partai politik dalam mencari anggota baru dan mengajak orang berbakat untuk berpartisipasi dalam proses politik. Rekrutmen yang dilakukan oleh partai politik tidak sebatas hanya untuk mencari anggota baru, tetapi juga merekrut dan mencalonkan anggota partai untuk posisi jabatan publik. Rekrutmen politik juga dimaknai luas, sebagai cara pemilihan, seleksi, dan pengangkatan para warga negara guna untuk diorbitkan menjadi calon-calon pemimpin dalam sistem politik pada umumnya dan pemerintahan pada khususnya (Haryanto, 1984: 41; Surbakti, 1992: 118).

Rekrutmen politik untuk pemilu diselenggarakan melalui tiga tahapan. Pertama, tahap sertifikasi, adalah tahap pendefinisian kriteria siapa yang dapat masuk dalam pencalonan, yang meliputi aturan-aturan pemilu, aturan-aturan partai, dan normanorma sosial. Kedua, tahap penominasian, mencakup ketersediaan (supply) calon yang memenuhi syarat dan permintaan (demand) dari penyeleksi saat memutuskan siapa yang dinominasikan. Ketiga, tahap pemilu, yakni tahap yang menentukan siapa yang memenangkan pemilu (Djojosoekarto \& Sandjaja, 2008: 181; Norris, 2006: 89; Sigit Pamungkas \& Parlindungan, 2011: 92) Tahap pertama dan kedua dari proses rekrutmen politik adalah domain penuh partai politik. Setelahnya, tahap ketiga adalah domain pemilih, yakni proses dimana pemilih menentukan siapa di antara calon yang ada dipilih sebagai pemimpin.

Salah satu tahapan penting pemilu adalah pencalonan. Menurut Surbakti (Surbakti, 1992) yang dimaksud dengan pencalonan adalah tata cara yang ditempuh peserta pemilu dalam mengajukan calon, yang meliputi siapa yang melakukan pencalonan, bagaimana cara menentukan calon, bagaimana cara menyusun daftar calon, dan apa persyaratan seorang calon.

Tata cara ini diatur rinci dengan Pasal dalam Undang-Undang Pemilu. Mengenai siapa yang mencalonkan, tersedia tiga pilihan, yakni oleh partai politik, oleh perseorangan, atau oleh keduanya. Amandemen UUD 45 mengatur rekrutmen politik 
sebagai ranah partai politik. Pasal 6 menegaskan partai politik yang mengusulkan pasangan calon presiden dan wakil presiden. Pasal 22E ayat (3) menegaskan partai politik sebagai peserta Pemilihan Umum Anggota DPR dan DPRD, sebagai peserta pemilu partai politik adalah institusi yang dalam Undang-Undang Pemilu diberi tugas mengusulkan siapa yang menjadi calon anggota DPR dan DPRD.

Hazan dan Rahat (Hazan \& Rahat, 2006: 110-114) menyebutkan empat hal penting dalam rekrutmen politik oleh partai politik, yakni (1) siapa yang dapat dinominasikan sebagai calon; (2) siapa yang melakukan seleksi calon (selectorate) ; (3) dimana calon diseleksi; dan (4) bagaimana calon diputuskan. Berdasar pada empat hal tersebut dihasilkan model pengelolaan rekrutmen partai yang dilakukan apakah inklusif atau eksklusif, dan apakah sentralistik atau desentralistik.

Soal siapa yang dicalonkan, Hazan dan Rahat (Hazan \& Rahat, 2006: 110-114) menyebut ada dua pola sistem seleksi kandidat, yang inklusif (terbuka) bagi siapapun dapat mencalonkan melalui partai politik dengan memenuhi syarat ringan (eligible), dan yang eksklusif(tertutup), manakala terdapat syarat yang ketat sehingga membatasi orang untuk ikut serta dalam seleksi kandidat. Disebut pula inklusif jika dalam proses seleksi melibatkan anggota partai dan sebaliknya disebut eksklusif jika seleksi hanya oleh satu individu ketua partai politik.

Selanjutnya disebut tersentralisasi jika seleksi secara eksklusif oleh penyeleksi partai tingkat nasional dan sebaliknya jika oleh partai cabang, dan disebut tertutup jika elit partai politik diberi hak penuh untuk menentukan siapa yang akan dicalonkan sebagai calon. Selanjutnya prosesnya disebut informal manakala tidak ada standar norma yang dibakukan, atau prosesnya formal, jika ada standarisasi prosedur yang dibakukan dan eksplisit. Karakter inklusif, desentralisasi, dan formal menunjuk pada ukuran rekrutmen politik yang demokratis, dan jika sebaliknya disebut tidak demokratis.

Berbeda dari pemilu legislatif dan pilpres yang membatasi pencalonan hanya oleh partai politik, untuk pilkada dibuka dua jalur dalam pencalonan, (1) melalui pengusulan oleh partai politik/gabungan partai politik yang memiliki kursi di DPRD dan memenuhi ambang batas pencalonan (20\% kursi DPRD atau 25\% suara sah di daerah pemilihan yang bersangkutan), dan (2) melalui jalur perseorangan (indipenden) yang didukung oleh sejumlah pemilih.

Namun demikian dominasi pencalonan pada jalur partai politik, terutama di daerah dengan pemilih gemuk hampir tidak ditemui calon melalui jalur ini. Langkanya calon melalui jalur persorangan diduga sebagai akibat syarat pencalonan berupa dukungan pemilih sebesar 6,5\%-10\% DPT Pilkada terakhir yang dinilai memberatkan. Dominasi partai politik dalam pencalonan memposisikan partai politik sebagai lembaga paling strategis yang menentukan siapa yang kelak menjadi penyelenggara negara.

Tidak semua negara menjadikan proses pencalonan oleh partai politik adalah wilayah otonomi partai politik, namun dalam Undang-Undang Pemilu kita proses ini diserahkan pada mekanisme demokrasi internal partai. Lepasnya peran publik dalam 
proses pencalonan oleh partai politik bisa membuka ruang bagi praktik pencalonan yang tidak demokratis.

Setidaknya peluang ini didukung oleh temuan studi kasus di Parlemen Inggris oleh Pippa Norris \& Lovenduski (1995), yang menemukan praktik proses rekrutmen politik oleh partai politik yang diskriminatif, yakni dalam proses seleksi calon kriteria tim seleksi menjadi bagian dari instrumen yang dapat digunakan untuk membuat adanya praktik diskriminasi. Studi ini menemukan kedekatan pribadi ternyata memberikan pengaruh yang besar kepada peluang terpilihnya seseorang untuk diputuskan sebagai calon, apalagi jika di dukung dengan iklim partai yang bersifat feodalistik dan oligarkis.

Rekrutmen politik tahap akhir adalah pemberian suara oleh pemilih, atau menjadi domain pemilih. Terkait dengan peluang keterpilihan dalam pilkada tidak lepas dari kepemilikan modal. Pasangan calon yang menguasai modal politik, modal sosial, modal ekonomi punya potensi untuk memenangi kontestasi. Ketiga jebis modal itu bisa berdiri sendiri-sendiri tanpa ada keterkaitan, tetapi acapkali berkait satu dengan yang lain (Marijan, 2006: 89). Pentingnya penguasaan sumber daya (modal) dalam kontestasi pilkada ini yang menjelaskan terdapatnya kecenderungan partai politik untuk mencalonkan orang yang punya kekuatan finansial (Haris, 2006: 54).

Pilkada menggunakan sistem pemilu First Past The Post (FPTP). Sistem pemilu FPTP memerebutkan satu kursi di daerah pemilihan, dalam sistem ini pemilih memilih calon dan calon yang dinyatakan menang adalah yang memiliki perolehan suara terbanyak. Oleh karenanya dalam pilkada terdapat fenomena personal vote, dimana faktor figur calon lebih menjadi dasar pertimbangan oleh pemilih dalam menentukan pilihan ketimbang faktor partai politik pengusung. Calon dinasti diuntungkan dalam sistem pemilu FPTP. Hal ini pula yang juga disadari oleh partai politik, karena itu untuk memastikan calon yang akan diusung terpilih, potensi partai politik memertimbangkan mengusung calon dinasti lebih besar.

Harus diakui calon dinasti memiliki keuntungan dalam bentuk popularitas. Keuntungan tersebut didapat dari patronnya sebagai kepala daerah sebelumnya. Eriyanto (2007) menemukan kepala daerah punya modal popularitas karena aktivitas berkantor selama menjabat. Modal popularitas adalah modal awal untuk keterpilihan, modal popularitas ini bisa diwariskan.

Bagi calon dinasti, nama keluarga (petahana) berfungsi sebagai merek (brandname) yang mudah dikenali pemilih (Akhtar \& Mushtaq, 2014). Peluang besar untuk menang juga ditemukan pada calon dinasti di Filipina (Asako, Iida, Matsubayashi, \& Ueda, 2012), negara tetangga yang pengalaman politiknya memiliki kemiripan dengan Indonesia. Calon berlatar belakang dinasti tersebut menikmati efek petahana (Querubin, 2013). Memang tidak selalu petahana terpilih lagi, begitu pun tidak selalu peluang menang itu bisa diwariskan kepada keluarganya (Fiva \& Smith, 2018). Namun hasil penelitian yang sudah dilakukan, persentase petahana yang terpilih jauh lebih besar dibanding yang kalah. Hasil Pilkada hingga Desember 2006, menunjukkan sebanyak 62,2\% petahana terpilih lagi (Eriyanto, 2007). 


\section{Praktik Politik Dinasti dalam Pilkada Serentak}

Pemberitaan media dan studi-studi yang sudah dilakukan menunjukkan fenomena politik dinasti terbangun melalui pilkada. Di sejumlah daerah didapati satu keluarga yang menguasai pos-pos politik, birokrasi dan ekonomi. Selain dinasti politik Atut dan dinasti politik Limpo, di sejumlah provinsi ditemukan walikota/bupati yang punya hubungan kekerabatan dengan gubernurnya.

Sebut saja beberapa contoh yang menarik untuk didiskusikan, seperti Rycko Menoza, Bupati Lampung Selatan (2010-2015) dan Handitya Narapati, Wakil Bupati Pringsewu (201-2016) adalah putra dari Gubernur Lampung Sjachroedin ZP (20042014); Ivan SJ Sarundajang, Wakil Bupati Minahasa (2013-2018) adalah putra Gubernur Sulawesi Utara Sinyo Harry Sarundajang (2010-2015); Syamsul Lutfi, Wakil Bupati Lombok Timur (2008-2013) adalah kakak dari Gubernur Nusa Tenggara Barat, Muhammad Zainul Majdi (2008-2018).

Bentuk lain, pasangan kepala daerah dan wakil kepala daerah dijabat satu keluarga, Walikota dan Wakil Walikota Bima, Nusa Tenggara Barat adalah kakak dan adik kandung, yaitu Qurais H Abidin dan A Rahman H Abidin (2010-2018) (Aritonang, 2013). Terdapat juga pola politik dinasti yang beda kamar seperti di Pasuruan, Jawa Timur (Republika, 2011) dan Kota Bontang, Kalimantan Timur (Pramasta, 2019) di mana Ketua DPRD adalah anak kandung Bupati. Di Kabupaten Bangkalan, Jawa Timur jabatan Bupati dan Ketua DPRD dipertukarkan antara ayah dan anak bergantian (CNN Indonesia, 2015). Selanjutnya, yang lebih umum adalah pola pewarisan jabatan dalam satu keluarga, jabatan yang ditinggal petahana digantikan oleh istri, anak, menantu atau saudara sekandung.

Pasca terbit Putusan MK No. 33/PUU-Xlll/2015 sebagai pembatalan larangan politik dinasti, sejumlah calon dari kerabat petahana maju dalam Pilkada 2015 dan terus berlanjut di pilkada setelahnya, dengan dalih menjamin kebebasan setiap masyarakat didalam partisipasi dan kontestasi politik, menghasilkan dinasti didalam sistem politik dan pemerintahan yang makin masif secara kuantitas dan tersebar di banyak daerah. Tabel 1 berikut adalah data yang menunjukkan jumlah calon berlatar belakang dinasti dalam Pilkada Serentak 2015, 2017 dan 2018 baik di tingkat provinsi maupun kabupaten/kota, disertai persentase hasil pemilihannya.

Tabel 1. Paslon Dinasti dalam Pilkada Pasca Putusan MK No. 33/PUU-XIll/2015

\begin{tabular}{llccc}
\hline Pilkada & Tingkat Daerah & $\begin{array}{c}\text { Paslon } \\
\text { Jalur } \\
\text { Parpol }\end{array}$ & $\begin{array}{c}\text { Paslon Jalur } \\
\text { Perseorangan }\end{array}$ & Paslon Terpilih \\
\hline Pilkada 2015 & Provinsi & 1 & - & $1(100 \%)$ \\
Pilkada 2017 & Kabupaten/Kota & 31 & 2 & $23(69,7 \%)$ \\
& Provinsi & 2 & - & $1(50 \%)$
\end{tabular}




\begin{tabular}{clccc} 
& Kabupaten/Kota & 10 & - & $7(70 \%)$ \\
Pilkada 2018 & Provinsi & 7 & - & $2(28,6 \%)$ \\
& Kabupaten/Kota & 6 & - & $3(50,0 \%)$ \\
\hline Jumlah & & 54 & 2 & $37(66 \%)$ \\
\hline
\end{tabular}

Sumber: diolah dari infopilkada.kpu.go.id dan berita pilkada dari media elektronik

Walaupun berdasar data juga tergambar bahwa keterpilihan calon berlatar belakang dinasti pada tiga gelombang pilkada ada tren menurun, namun secara keseluruhan calon berlatar belakang dinasti yang terpilih sangat tinggi mencapai sebesar $66 \%$. Persentase keterpilihan calon dinasti memiliki kemiripan dengan persentase keterpilihan petahana. Hasil Pilkada serentak 2015, 2017 dan 2018 menunjukkan ada sebanyak $61,3 \%$ daerah yang dimenangkan calon petahana. Bisa ditarik kesimpulan calon petahana ataupun calon berlatar belakang dinasti adalah lawan berat bagi calon penantang (lihat tabel 2).

Tabel 2. Daerah Yang Calon Petahana Terpilih Lagi

\begin{tabular}{lccc}
\hline Pilkada & $\begin{array}{c}\text { Jumlah Daerah } \\
\text { yang pilkada }\end{array}$ & $\begin{array}{c}\text { Jumlah Daerah } \\
\text { ada calon } \\
\text { petahana }\end{array}$ & $\begin{array}{c}\text { Jumlah Daerah } \\
\text { yang calon petahana } \\
\text { terpilih }\end{array}$ \\
\hline Pilkada 2015 & 269 & 144 & $96(66,7 \%)$ \\
Pilkada 2017 & 101 & 67 & $46(68,6 \%)$ \\
Pilkada 2018 & 171 & 128 & $64(50 \%)$ \\
Jumlah & 541 & 339 & $208(61,3 \%)$ \\
\hline
\end{tabular}

Sumber: diolah dari infopilkada.kpu.go.id dan berita pilkada dari media elektronik

Di sejumlah daerah dinasti politik dibangun melalui pilkada. Komite Pemantauan Pelaksanaan Otonomi Daerah (KPPOD), lembaga independen pemantauan pelaksanaan otonomi daerah, menemukan kecenderungan politik dinasti mencapai 10-20\% daerah di Indonesia. Praktik tersebut banyak muncul di Banten, Sulawesi Utara, Sulawesi Selatan, Jawa Barat, dan Yogyakarta (KPPOD, 2015). Polanya, setelah berkuasa kepala daerah memiliki insentif dan sarana untuk mempertahankan posisi mereka di kekuasaan, ia menyiapkan anggota keluarganya untuk dicalonkan dalam pemilu legislatif, nasional dan lokal, dan disiapkan pula untuk menggantikan dirinya kelak setelah periode masa jabatannya habis. Hal ini dipermudah karena posisi kepala daerah juga sebagai ketua partai di daerahnya. Ambil contoh, ada delapan keluarga Gubernur Sulawesi Selatan Syahrul Yasin Limpo (2007-2018) yang mendapat jabatan melalui pemilu, mayoritasnya diusung oleh Partai Golkar (Qurtuby, 2017). Mendiang Yasin Limpo adalah pendiri Golkar dan Syahrul Yasin Limpo adalah Ketua Dewan Pimpinan Daerah (DPD) Partai Golkar Sulawesi Selatan (2009-2013) (Viva.co, 2009).

Sistem politik demokrasi melindungi hak setiap orang sebagai calon di pilkada, namun politik dinasti menutup pintu akses peluang yang yang sama bagi setiap orang. Praktik politik dinasti menghasilkan fenomena pencalonan dalam pilkada di sejumlah daerah dikuasai oleh segelintir orang yang masih sekeluarga. Ditilik dari probabilitas calon berlatar belakang dinasti yang tinggi untuk menang, maka politik dinasti membuat 
proses sirkulasi elit yang memerintah terhenti di satu kelompok keluarga. Surbakti (1992) menyebutkan salah satu alasan mengapa pemilu dipandang sebagai unsur penting sistem politik demokrasi, karena pemilu merupakan prosedur dan mekanisme perubahan politik secara tertib dan periodik, baik perubahan sirkulasi elit politik maupun perubahan arah dan pola kebijakan publik. Berbeda dari alasan pentingnya pemilu tersebut, praktik politik dinasti justru akan melanggengkan kekuasaan pada satu keluarga dan karenanya sulit diharapkan ada perubahan arah dan pola kebijakan publik. Ini karena calon berlatar belakang dinasti yang terpilih akan bekerja di bawah kontrol patronnya. Politik dinasti juga ditengarai berbau korupsi karena dimungkinkan sebagai mekanisme pertahanan perburuan rente. Kajian Indonesia Corruption Watch (ICW) menunjukkan bahwa lebih dari 90\% kasus korupsi di daerah melibatkan politik dinasti (Tempo.co, 2015).

Politik dinasti juga berpotensi terpilihnya pemimpin daerah yang buruk. Rekrutmen partai politik berbasis politik dinasti berpeluang mengabaikan kualitas personal calon. Pertimbangan kekuatan modal calon menjadi basis seleksi ketimbang kapasitas calon. Ahmad Wazir Nofiadi, Bupati Ogan Ilir hasil Pilkada 2015 adalah contoh kualitas bupati yang buruk, baru sebulan menjabat sudah tersandung kasus narkoba. Nofiadi adalah putra Bupati Mawardi Yahya (2005-2015) (Tempo, 2016)

\section{Rekrutmen Calon oleh Partai Politik dalam Pilkada}

Suburnya praktik politik dinasti memberi gambaran bahwa perekrutan calon kepala daerah dan wakil kepala daerah oleh partai politik tidak dilakukan secara demokratis dan transparan. Kajian literatur menunjukkan kebanyakan partai politik bersikap pragmatis dengan memasang calon yang punya popularitas (tingkat pengenalan pemilih terhadap calon) dan elektabilitas (keinginan pemilih untuk memilih) tinggi berdasar pada hasil survei opini publik, serta dipastikan orang yang bisa memodali dirinya sendiri.

Seleksi calon juga dilakukan secara terpusat (tersentralisasi) yang peran pengurus partai politik pusat (DPP) sangat besar. Peran kuat dari DPP dalam pencalonan pilkada ini bahkan diformalkan mulai Pilkada 2015. Pasal 42 angka (4) (5) (6) UU Pilkada No. 8 tahun 2015 menegaskan bahwa dokumen pengusulan calon kepala daerah dan wakil kepala daerah kepada KPU setempat harus disertai surat keputusan (SK) dari Pengurus Pusat Partai Politik (DPP) tentang persetujuan atas calon yang diusulkan (dinominasikan).

Undang-Undang Pilkada mengatur syarat yang bersifat umum bagi calon kepala daerah dan wakil kepala daerah, yang dipastikan menjamin hak konstitusional setiap warga negara untuk dipilih (sebagai calon). Persyaratan yang dinilai membatasi hak warga negara, seperti aturan yang membatasi hak politik calon berlatar belakang dinasti telah dikoreksi oleh Putusan Mahkamah Konstitusi. Perubahan aturan syarat calon kepala daerah dan wakil kepala daerah bisa disimak dalam tabel 3. 
Tabel 3. Perubahan Aturan Syarat Calon kepala Daerah \& Wakil Kepala Daerah

\begin{tabular}{|c|c|c|}
\hline $\begin{array}{l}\text { UU 32/2004 jo UU } \\
12 / 2008\end{array}$ & UU 8/2015 & UU 10/2016 \\
\hline $\begin{array}{l}\text { Bertakwa kepada Tuhan } \\
\text { YME }\end{array}$ & idem & idem \\
\hline $\begin{array}{l}\text { Setia kepada } r \text { Pancasila } \\
\text { sebagai Dasar Negara, UUD } \\
\text { Negara Republik Indonesia } \\
\text { Tahun 1945, cita-cita } \\
\text { Proklamasi 17 Agustus } 1945, \\
\text { dan kepada NKRI serta } \\
\text { Pemerintah }\end{array}$ & $\begin{array}{l}\text { Setia kepada Pancasila, UUD } \\
\text { Negara Republik Indonesia } \\
\text { Tahun 1945, cita-cita Proklamasi } \\
\text { Kemerdekaan } 17 \text { Agustus 1945, } \\
\text { dan NKRI }\end{array}$ & idem \\
\hline $\begin{array}{l}\text { Berpendidikan sekurang- } \\
\text { kurangnya sekolah lanjutan } \\
\text { tingkat atas dan/atau } \\
\text { sederajat }\end{array}$ & idem & idem \\
\hline $\begin{array}{l}\text { Berusia sekurang-kurangnya } \\
30 \text { (tiga puluh) tahun }\end{array}$ & $\begin{array}{l}\text { Berusia paling rendah } 30 \text { (tiga } \\
\text { puluh) tahun untuk Calon } \\
\text { Gubernur dan Calon Wakil } \\
\text { Gubernur serta } 25 \text { (dua puluh } \\
\text { lima) tahun untuk Calon Bupati } \\
\text { dan Calon Wakil Bupati serta } \\
\text { Calon Walikota dan Calon Wakil } \\
\text { Walikota }\end{array}$ & idem \\
\hline $\begin{array}{l}\text { Sehat jasmani dan rohani } \\
\text { berdasarkan hasil } \\
\text { pemeriksaan kesehatan } \\
\text { menyeluruh dari tim dokter; } \\
\text { Tidak pernah dijatuhi pidana } \\
\text { penjara berdasarkan putusan } \\
\text { pengadilan yang telah } \\
\text { memperoleh kekuatan } \\
\text { hukum tetap karena } \\
\text { melakukan tindak pidana } \\
\text { yang diancam dengan pidana } \\
\text { penjara paling lama } 5 \text { (lima) } \\
\text { tahun atau lebih }\end{array}$ & $\begin{array}{l}\text { Mampu secara jasmani dan } \\
\text { rohani berdasarkan hasil } \\
\text { pemeriksaan kesehatan } \\
\text { menyeluruh dari tim dokter } \\
\text { Tidak pernah dijatuhi pidana } \\
\text { penjara berdasarkan putusan } \\
\text { pengadilan yang } r \text { telah } \\
\text { memperoleh kekuatan hukum } \\
\text { tetap karena melakukan tindak } \\
\text { pidana yang diancam dengan } \\
\text { pidana penjara } 5 \text { (lima) tahun } \\
\text { atau lebih (dibolehkan bersyarat } \\
\text { berdasar Putusan MK No. } \\
\text { 42/PUU-XIII/2015 } \\
\text { mantan terpidana yang telah } \\
\text { secara terbuka dan jujur } \\
\text { mengemukakan kepada publik } \\
\text { bahwa yang bersangkutan } \\
\text { mantan terpidana) }\end{array}$ & $\begin{array}{l}\text { Tidak pernah sebagai } \\
\text { terpidana berdasarkan } \\
\text { putusan pengadilan yang } \\
\text { telah memperoleh } \\
\text { kekuatan hukum tetap } \\
\text { atau bagi mantan } \\
\text { terpidana telah } \\
\text { terbuka dan jujur } \\
\text { mengemukakan kepada } \\
\text { publik bahwa yang } \\
\text { bersangkutan mantan } \\
\text { terpidana }\end{array}$ \\
\hline $\begin{array}{l}\text { Tidak sedang dicabut hak } \\
\text { pilihnya berdasarkan putusan } \\
\text { pengadilan yang telah } \\
\text { memperoleh rekuatan } \\
\text { hukum tetap }\end{array}$ & idem & idem \\
\hline $\begin{array}{l}\text { Mengenal daerahnya dan } \\
\text { dikenal oleh masyarakat di } \\
\text { daerahnya }\end{array}$ & - & - \\
\hline
\end{tabular}




\begin{tabular}{|c|c|c|}
\hline $\begin{array}{l}\text { UU } 32 / 2004 \text { jo UU } \\
12 / 2008\end{array}$ & UU 8/2015 & UU $10 / 2016$ \\
\hline $\begin{array}{l}\text { Menyerahkan daftar } \\
\text { kekayaan pribadi dan } \\
\text { bersedia untuk diumumkan }\end{array}$ & $\begin{array}{l}\text { Menyerahkan daftar kekayaan } \\
\text { pribadi }\end{array}$ & idem \\
\hline $\begin{array}{l}\text { Tidak sedang memiliki } \\
\text { tanggungan utang secara } \\
\text { perseorangan dan/atau } \\
\text { secara badan hukum yang } \\
\text { menjadi tanggung jawabnya } \\
\text { yang merugikan keuangan } \\
\text { negara }\end{array}$ & idem & idem \\
\hline $\begin{array}{lr}\text { Tidak sedang dinyatakan } \\
\text { pailit berdasarkan putusan } \\
\text { pengadilan yang telah } \\
\text { memperoleh rratan } \\
\text { hukum tetap }\end{array}$ & idem & idem \\
\hline $\begin{array}{l}\text { Tidak pernah melakukan } \\
\text { perbuatan tercela (dihapus } \\
\text { dalam UU 12/2008) }\end{array}$ & $\begin{array}{lrr} & \text { Tidak pernah melakukan } \\
\text { perbuatan tercela yang } \\
\text { dibuktikan dengan surat } \\
\text { keterangan catatan kepolisian }\end{array}$ & idem \\
\hline $\begin{array}{l}\text { Memiliki Nomor Pokok } \\
\text { Wajib Pajak (NPWP) atau } \\
\text { bagi yang belum mempunyai } \\
\text { NPWP wajib mempunyai } \\
\text { bukti pembayaran pajak }\end{array}$ & $\begin{array}{l}\text { Memiliki Nomor Pokok Wajib } \\
\text { Pajak dan memiliki laporan pajak } \\
\text { pribadi }\end{array}$ & idem \\
\hline $\begin{array}{l}\text { Menyerahkan daftar riwayat } \\
\text { hidup lengkap yang memuat } \\
\text { antara lain riwayat } \\
\text { pendidikan dan pekerjaan } \\
\text { serta keluarga kandung, } \\
\text { suami atau istri }\end{array}$ & - & - \\
\hline $\begin{array}{l}\text { Belum pernah menjabat } \\
\text { sebagai kepala daerah atau } \\
\text { wakil kepala daerah selama } 2 \\
\text { (dua) kali masa jabatan dalam } \\
\text { jabatan yang sama }\end{array}$ & $\begin{array}{l}\text { Belum pernah menjabat sebagai } \\
\text { Gubernur, Bupati, dan Walikota } \\
\text { selama } 2 \text { (dua) kali masa jabatan } \\
\text { dalam jabatan yang sama untuk } \\
\text { Calon Gubernur, Calon Bupati, } \\
\text { dan Calon Walikota }\end{array}$ & $\begin{array}{l}\text { Belum pernah menjabat } \\
\text { sebagai Gubernur, Wakil } \\
\text { Gubernur, Bupati, Wakil } \\
\text { Bupati, Walikota, dan } \\
\text { Wakil Walikota selama } 2 \\
\text { (dua) kali masa jabatan } \\
\text { dalam jabatan yang sama } \\
\text { untuk Calon Gubernur, } \\
\text { Calon Wakil Gubernur, } \\
\text { Calon Bupati, Calon } \\
\text { Wakil Bupati, Calon } \\
\text { Walikota, dan Calon } \\
\text { Wakil Walikota }\end{array}$ \\
\hline- & $\begin{array}{l}\text { Belum pernah menjabat sebagai } \\
\text { Gubernur, Bupati, dan Walikota } \\
\text { untuk Calon Wakil Gubernur, } \\
\text { Calon Wakil Bupati, dan Calon } \\
\text { Wakil Walikota }\end{array}$ & $\begin{array}{l}\text { belum pernah menjabat } \\
\text { sebagai Gubernur untuk } \\
\text { calon Wakil Gubernur, } \\
\text { atau Bupati/Walikota } \\
\text { untuk Calon Wakil } \\
\text { Bupati/Calon Wakil }\end{array}$ \\
\hline
\end{tabular}




\begin{tabular}{|c|c|c|}
\hline $\begin{array}{l}\text { UU } 32 / 2004 \text { jo UU } \\
12 / 2008\end{array}$ & UU 8/ 2015 & UU $10 / 2016$ \\
\hline & & $\begin{array}{l}\text { Walikota pada daerah } \\
\text { yang sama }\end{array}$ \\
\hline- & $\begin{array}{l}\text { Berhenti dari jabatannya bagi } \\
\text { Gubernur, Wakil Gubernur, } \\
\text { Bupati, Wakil Bupati, Walikota, } \\
\text { dan Wakil Walikota yang } \\
\text { mencalonkan diri di daerah lain } \\
\text { sejak ditetapkan sebagai calon }\end{array}$ & idem \\
\hline $\begin{array}{l}\text { Tidak dalam status sebagai } \\
\text { penjabat kepala daerah }\end{array}$ & $\begin{array}{l}\text { Tidak berstatus sebagai penjabat } \\
\text { Gubernur, penjabat Bupati, dan } \\
\text { penjabat Walikota }\end{array}$ & idem \\
\hline- & $\begin{array}{l}\text { Tidak memiliki konflik } \\
\text { kepentingan dengan petahana } \\
\text { (dihapus melalui Putusan MK } \\
\text { No. 33/PUU-Xlll/2015) }\end{array}$ & - \\
\hline- & $\begin{array}{l}\text { Memberitahukan pencalonannya } \\
\text { sebagai Gubernur, Wakil } \\
\text { Gubernur, Bupati, Wakil Bupati, } \\
\text { Walikota, dan Wakil Walikota } \\
\text { kepada Pimpinan DPR bagi } \\
\text { anggota DPR, kepada Pimpinan } \\
\text { DPD bagi anggota DPD, atau } \\
\text { kepada Pimpinan DPRD bagi } \\
\text { anggota DPRD } \\
\text { (diubah berdasar Putusan MK } \\
\text { No. 46/PUU-Xll//2015 anggota } \\
\text { DPR/DPD/DPRD } \\
\text { mengundurkan diri setelah } \\
\text { ditetapkan sebagai paslon ) }\end{array}$ & $\begin{array}{lr}\text { Menyatakan } & \text { secara } \\
\text { tertulis pengunduran diri } \\
\text { sebagai anggota DPR, } \\
\text { anggota DPD, dan } \\
\text { anggota DPRD } & \text { sejak } \\
\text { ditetapkan } & \text { sebagai } \\
\text { pasangan calon } & \text { peserta } \\
\text { Pemilihan }\end{array}$ \\
\hline- & $\begin{array}{l}\text { Mengundurkan diri sebagai } \\
\text { anggota TNI, Polri, dan PNS } \\
\text { sejak mendaftarkan diri sebagai } \\
\text { calon (diubah berdasar Putusan } \\
\text { MK No. 46/PUU-Xlll/2015 } \\
\text { PNS mengundurkan diri setelah } \\
\text { ditetapkan sebagai pasangan } \\
\text { calon) }\end{array}$ &  \\
\hline- & $\begin{array}{lll}\text { Berhenti dari jabatan } & \text { pada } \\
\text { BUMN atau BUMD } & \text { sejak } \\
\text { ditetapkan sebagai calon } & \end{array}$ & idem \\
\hline $\begin{array}{l}\text { Mengundurkan diri } r \text { sejak } \\
\text { pendaftaran bagi kepala } \\
\text { daerah dan/atau wakil kepala } \\
\text { daerah yang masih } \\
\text { menduduki jabatannya } \\
\text { (ditambahkan dalam UU } \\
12 / 2008 \text { ) }\end{array}$ & - & - \\
\hline
\end{tabular}

Sumber: Pasal 58 UU No. 32/2004, Pasal 58 UU No. 12/2008, Pasal 7 UU No.8/2015, Pasal 7 (2) UU No.10/2016, dan Putusan MK yang terkait 
Berdasar tabel 3 maka syarat calon dalam Undang-Undang Pilkada tidak menghambat calon berlatar belakang dinasti. Hal yang sama ditemukan dalam ketentuan tentang syarat calon dalam pilkada oleh semua partai politik yang juga mengikuti norma dalam Undang-Undang Pilkada. Hanya sebagian partai politik yang memperketat syarat calon tetapi hanya untuk kader internal dengan menambahkan beberapa syarat baru, misalnya PDIP yang menambahkan syarat minimal sudah 3 tahun sebagai anggota partai bagi kader internal. Kajian literatur atas proses rekrutmen politik untuk pencalonan pilkada oleh partai politik menemukan pola sebagai berikut:

1) Semua partai politik dalam merekrut calon kepala daerah dan wakil kepala daerah melibatkan semua tingkatan kepengurusan (diatur dalam AD/ART, atau Peraturan Partai, atau Surat Edaran)

2) Hampir semua partai politik membuka pendaftaran calon dari sumber internal (kader) dan eksternal (bukan kader)

3) Sebagian partai politik menambah syarat khusus bagi calon dari internal (kader)

4) Hampir semua partai politik memposisikan pengurus partai pusat (DPP) sebagai penentu akhir siapa yang dinominasikan, dan pelibatan pengurus daerah sebatas menerima pendaftaran, memverifikasi dokumen persyaratan, mengerucutkan calon yang dinominasikan, dan mengusulkan calon yang dinominasikan

5) Hampir semua partai mempertimbangkan kemampuan finansial calon

6) Hampir semua partai mempertimbangkan tingkat popularitas dan elektabilitas calon berdasar hasil riset opini oleh lembaga survei profesional

7) Sebagian partai politik memungut biaya pendaftaran

8) Keputusan akhir tentang siapa yang dicalonkan di tangan DPP menjadikan dinamika di lapangan memengaruhi proses seleksi dari proses yang semestinya formal sesuai standar norma menjadi proses yang informal. Dinamika di lapangan dimaksud termasuk manakala ada calon petahana dan/atau calon berlatar belakang dinasti.

Simpulan di atas dibangun dari data dalam tabel 4 berikut, yang menunjukkan model rekrutmen politik pada hampir semua partai politik bersifat sentralistik karena peran DPP besar sebagai pemutus kata akhir siapa yang dicalonkan.

Tabel 4. Model Rekrutmen Politik Pilkada Oleh Partai Politik

\begin{tabular}{l|ccc} 
Rekrutmen Politik & Asal Calon & Seleksi Calon & Keputusan Akhir \\
\hline PDIP & Terbuka-Terbatas & DPP & DPP \\
Partai Golkar & Terbuka-Terbatas & DPP & DPP \\
Partai Demokrat & Terbuka & DPD & DPP \\
Partai Gerindra & Terbuka & DPD & DPP \\
Partai Nasdem & Terbuka & DPC \& DPD & DPP \\
PKB & Terbuka & DPC & DPP \\
PKS & Terbuka-Terbatas & Pemilu Internal & DPP
\end{tabular}


PPP PAN
Terbuka

DPD

Terbuka
DPC
DPP

DPD (untuk calon

bupati/walikota)

DPP (untuk calon

gubernur)

Sumber: Studi literatur hasil penelitian tentang rekrutmen politik pilkada di sejumlah daerah.

Keterangan:

- DPC: Kepengurusan Partai Kabupaten/Kota (sebagian partai menyebut DPD)

- DPD: Kepengurusan Partai Provinsi (sebagaian partai menyebut DPW)

- DPP : Kepengurusan Partai Nasional

- Terbuka terbatas jika menambah syarat khusus bagi calon internal, partai tersebut juga mengutamakan kader internal

Kajian yang dilakukan Nyarwi (2007) juga menemukan semua tingkat kepengurusan partai politik, pusat-kabupaten/kota, terlibat. Namun hasil akhir siapa yang dicalonkan dari proses panjang ini menjadi domain pengurus pusat (DPP). Selain bersifat sentralistik dalam pencalonan, dalam tubuh partai politik juga terbentuk dinasti politik yang berpusat pada sosok ketua umum, hal yang sama di kepengurusan partai tingkat daerah . Jabatan ketua partai tingkat daerah umumnya dipegang oleh petahana. Mengacu pada temuan studi Pippa Norris \& Lovenduski (1995) kondisi ini buruk bagi tumbuhnya demokrasi internal partai dalam pencalonan, seleksi pencalonan partai berpotensi menjadi elitis dan "tertutup" hanya terbatas untuk calon berlatar belakang dinasti.

Persyaratan bagi calon kepala daerah dan wakil kepala daerah, baik yang diatur dalam regulasi pilkada maupun dalam aturan internal partai politik tidak menghambat bagi tumbuh suburnya politik dinasti melalui pintu pencalonan. Berdasar data dalam tabel 4 tampak bahwa organisasi partai politik dalam pencalonan dikelola secara sentralistis yang otoritas DPP sangat besar dalam menentukan pasangan calon yang akan diusung. Pada hampir semua partai politik rekomendasi ketua umum partai adalah kata akhir yang menentukan gagal-tidaknya seorang calon yang diusung oleh partai itu, sehingga berdampak calon yang diusulkan dari bawah terpotong di DPP. Faktor yang juga penting dalam seleksi calon adalah kemampuan finansial dan tingkat popularitas dan elektabilitas calon, hampir semua partai politik menyelenggarakan survei untuk mengukur derajat popularitas dan eletabilitas calon. Calon yang diusulkan dari bawah akan terpangkas di DPP karena faktor popularitas dan elektabilitas yang rendah. Kondisi ini memberi karpet merah bagi calon berlatar belakang dinasti yang dari ukuran finansial, popularitas dan elektabilitas memenuhi syarat.

Rekrutmen politik tidak hanya ranah partai politik dalam pencalonan, tetapi juga ranah pemilih yang akan memberi suara. Oleh sebab itu dalam melakukan fungsi 
rekrutmen politik, partai politik cenderung memertimbangkan "selera pasar" pemilih. Oleh sebab itu, faktor popularitas dan elektabilitas calon menjadi pertimbangan rekrutmen politik yang penting bagi partai politik. Calon berlatar belakang dinasti lazimnya unggul dalam survei popularitas dan elektabilitas.

Praktik penominasian calon oleh partai politik dalam pilkada yang berdasar pada kemampuan finansial calon juga menjadi temuan kajian S. Haris, 2006: 54). Faktor ini telah membatasi siapa-siapa yang akan dicalonkan oleh partai politik menjadi sempit (eksklusif) hanya untuk mereka yang punya modal, dan yang termasuk diuntungkan adalah calon berlatar belakang dinasti. Pertimbangan kemampuan finansial tidak lepas dari menguatnya politik transaksional di kelompok pemilih, bahwa pemilih makin permisif terhadap politik uang atau mengalami proses normalisasi, bahkan peringkat Indonesia di urutan ketiga negara di dunia yang paling banyak melakukan politik uang (Muhtadi, 2018: 95).

\section{Penutup}

Sejumlah keuntungan elektoral memang dimiliki oleh calon berlatar belakang dinasti, mereka punya keuntungan nama keluarga sehingga populer dan berdampak pada hasil survei elektabilitas yang cenderung lebih tinggi di antara para peserta dalam pencalonan. Selain itu, calon berlatar belakang dinasti menguasai semua sumber daya (modalitas) yang yang melekat pada sosok patronnya (petahana) yang dapat diwariskan. Kepentingan pragmatis memenangi pemilihan, menjadikan partai politik dalam menjalankan fungsi rekrutmen politik mengesampingkan tujuan berpolitik untuk kebaikan bersama, sehingga dalam rekrutmen politik lebih menonjol berdasar pada pertimbangan popularitas, elektabilitas dan kekuatan modal finansial calon atau "selera pasar" pemilih, yang mencerminkan kepentingan politik yang sangat pragmatis.

Artikel ini menunjukkan bahwa rekrutmen politik untuk pencalonan pilkada oleh partai politik meski terkesan terbuka, dengan menerima pendaftaran calon dari internal (kader) dan eksternal (non-kader), namun proses seleksinya bersifat sentralistis dan informal, serta menjadi eksklusif ketika partai politik menambahkan syarat tingkat popularitas dan elektabilitas calon, serta kemampuan finasial calon, sehingga lebih memberi jalan (kepastian untuk dinominasikan) bagi calon yang berlatar belakang dinasti. Temuan ini mengkonfirmasi adanya masalah dalam sistem perekrutan calon oleh partai politik dalam pilkada.

Sejumlah studi menunjukkan jika politik dinasti memperlemah kompetisi politik dalam pemilu (Mendoza et al., 2016; Mietzner, 2012; Querubin, 2013). Demikian pula hampir semua studi politik dinasti menemukan sisi negatifnya, jika pun studi yang menemukan aspek positif dari politik dinasti (Lacroix et al., 2019) jumlahnya hanya dalam hitungan jari. Akibat negatif dari politik dinasti, antara lain: (1) ketidaksetaraan 
dalam pencalonan antara calon berlatar belakang dinasti dan yang bukan berlatar belakang dinasti; (2) probabilitas keterpilihan yang lebih besar pada calon berlatar belakang dinasti telah menghalangi sirkulasi elit menjadi berhenti di satu keluarga dan karenanya menghalangi adanya perubahan kebijakan; (4) politik dinasti menghalangi bekerjanya mekanisme pengawasan diantara lembaga-lembaga politik oleh karena dikuasai oleh satu keluarga, dan (5) politik dinasti juga terbukti dekat dengan praktik KKN (perilaku predatoris) di daerah.

Praktik politik dinasti tidak bisa diputus melalui pasal di Undang-Undang Pilkada. Hak memilih dan dipilih bersifat universal dan dilindungi dalam konstitusi. Untuk itu partai politiklah yang semestinya bisa melakukan upaya pengendalian menguatnya politik dinasti. Partai politik semestinya ikut bertanggung jawab mencegah akumulasi kekuasaan dalam satu keluarga dengan memastikan jabatan politik yang potensi punya conflict of interest tidak dikuasakan pada keluarga yang sama. Partai politik bisa menggunakan ruang pencalonan sebagai cara mengendalikan politik dinasti. Pengendalian menguatnya politik dinasti dengan menegakkan demokrasi internal partai (intra-party democracy) dalam rekrutmen calon. Penegakkan demokrasi internal partai ditempuh dengan cara lebih luas melibatkan kader/anggota partai dalam penentuan calon pilkada yang diusung di sebagian besar tahapan dan dibakukan dalam AD/ART. Proses rekrutmen terbuka dan terdesentralisasi yang melibatkan kader/anggota partai, serta melalui proses yang formal akan mengurangi praktik diskriminasi dalam pencalonan.

\section{Ucapan Terima Kasih}

Terima kasih kepada Priyatno Harsasto yang telah membantu mereview tulisan awal ini melalui diskusi-diskusi yang menarik.

\section{Pendanaan}

Penulis menerima bantuan pembiayaan untuk penelitian melalui dana DIPA Fakultas Ilmu Sosial dan Ilmu Politik Universitas Diponegoro 2018.

\section{Daftar Pustaka}

Agustino, L. (2010). Dinasti Politik Pasca-Otonomi Orde Baru: Pengalaman Banten. Furnal Prisma.

Akhtar, N., \& Mushtaq, S. (2014). The Dynastic Elites and its Recruitment in Political Process of Pakistan. Berkeley Journal of Social Sciences, 4(4), 1-18.

Aritonang, D. R. (2013). 60 Orang yang Terlibat Politik Dinasti! Retrieved February 2, 2020, from https://nasional.kompas.com/read/2013/10/ 18/1850579/60.Orang.yang.Terlibat.Politik.Dinasti.

Asako, Y., Iida, T., Matsubayashi, T., \& Ueda, M. (2012). Dynastic Politicians: Theory and Evidence From Japan. Waseda University Organization for Fapan-US Studies: Working Paper, (201201). 
Bimantara, N., \& Harsasto, P. (2018). Analisis Politik Dinasti di Kabupaten Kediri. Journal of Politic and Government Studies, 7(04), 201-210.

Cahyaningtyas, N. (2018). Politik Dinasti di Kabupaten Kediri: Pertukaran Sosial Tim Pemenangan Bupati Haryanti-Masykuri dengan Warga Desa Pare Lor Kecamatan Kunjang. Paradigma, 6(1).

CNN Indonesia. (2015). Kisah Dinasti Fuad: Korbankan Istri Muda demi Putra Mahkota. Retrieved February 2, 2020, from https://www. cnnindonesia.com/nasional/20150709080558-32-65335/kisah-dinasti-fuadkorbankan-istri-muda-demi-putra-mahkota?

Creswell, J. (2014). Penelitian Kualitatif \& Desain Riset: Memilih di Antara Lima Pendekatan (A. Lazuardi, Trans.). Togyakarta: Pustaka Pelajar.(Original Work Published 1998).

Djojosoekarto, A., \& Sandjaja, U. (2008). Transformasi Demokratis Partai Politik di Indonesia: Model, Strategi, dan Praktek. Partnership for Governance Reform dan Strategic Transformation Institute.

Eriyanto. (2007). Incumbent dan Pilkada. ajian Bulanan Lingkaran Survei Indonesia (LSI).

Fiva, J. H., \& Smith, D. M. (2018). Political Dynasties and The Incumbency Advantage in Party-Centered Environments. American Political Science Review, 112(3), 706-712.

Haris, S. (2006). Kecenderungan Pencalonan dan Koalisi Partai dalam Pilkada Langsung 2005. In S. Nuryanti (Ed.), Analisis Proses dan Hasil Pilkada Langsung 2005 (pp. 47-68).

Haris, Syamsuddin. (2006). Membangun format baru otonomi daerah. Jakarta: Yayasan Obor Indonesia.

Haryanto. (1984). Partai Politik: Suatu Tinjauan Umum. Jogjakarta: Liberty.

Hazan, R. Y., \& Rahat, G. (2006). Candidate Selection:Methods And Consequences. dalam Richard S. Katz and William Crotty. Handbook of Party Politics. London: SAGE Publications.

Hidayat, S. (2008). Shadow State...? Bisnis dan Politik di Provinsi Banten. Politik Lokal Di Indonesia.

Katz, R. S. (2001). The Problem of Candidate Selection and Models of Party Democracy. Party Politics, 7(3), 277-296.

KPPOD. (2015). Meretas Politik Dinasti Kepala Daerah. Retrieved from https://www.kppod.org/berita/view?id=274

Marijan, K. (2006). Demokratisasi di Daerah: Pelajaran dari Pilkada Secara Langsung. Diterbitkan bersama Pustaka Eureka [dan] PusDeHAM.

Mendoza, R. U., Beja Jr, E. L., Venida, V. S., \& Yap, D. B. (2016). Political Dynasties and Poverty: Measurement and Evidence of Linkages in The Philippines. Oxford Development Studies, 44(2), 189-201.

Mietzner, M. (2012). Indonesia: Yudhoyono's Legacy between Stability and Stagnation. Southeast Asian Affairs, 34-119. Retrieved from https://www.jstor.org/stable/41713990

Muhtadi, B. (2018). Komoditas Demokrasi: Efek Sistem Pemilu Terhadap Maraknya Jual Beli Suara. M. Sukmajati $\&$ A. Perdana, Pembiayaan Pemilu Di 
Indonesia, 95-117.

Norris, P. (2006). Recruitment. dalam Richard S. Katz and William Crotty. Handbook of Party Politics. London: SAGE Publications.

Norris, Pippa, \& Lovenduski, J. (1995). Political Recruitment: Gender, Race and Class in

The British Parliament. Cambridge University Press.

Nyarwi, A. (2007). Siasat Partai Politik dan Strategi Pencalonan. Kajian Bulanan Lingkaran Survei Indonesia (LSI).

Pamungkas, S. (2009). Perihal Pemilu. Yogyakarta: Laboratorium J IP dan JIP Fisipol-UGM.

Pamungkas, Sigit, \& Parlindungan, U. (2011). Partai Politik: Teori dan Praktik di Indonesia. Institute for Democracy and Welfarism.

Pramasta, D. B. (2019). Ketika Dinasti Politik Semakin Menguat... Retrieved

February 2, 2020, from https://www.kompas.com/tren/read/2019/

10/06/073000765/ketika-dinasti-politik-semakin-menguat-?page=all

Querubin, P. (2013). Family and Politics: Dynastic Incumbency Advantage in The

Philippines. Unpublished Manuscript.

Qurtuby, S. al. (2017). Pro-Kontra Perppu No. 2 Tahun 2017. Retrieved May 8, 2018, from https://www.dw.com/id/pro-kontra-perppu-no-2-tahun$2017 / a-39827177$

Rusnaedy, Z., \& Purwaningsih, T. (2018). Keluarga Politik Yasin Limpo Pada Pemilihan Kepala Daerah di Kabupaten Gowa Tahun 2015. Jurnal Politik, 3(2), 301-322.

Surbakti, R. (1992). Memahami Ilmu Politik. Grasindo.

Sutisna Oteng. (2000). Administrasi Pendidikan Dasar Teoretis untuk Praktek Profesional. Bandung: Angkasa.

Tempo.co. (2015). Melanggengkan Politik Dinasti. Retrieved February 2, 2020, from https://kolom.tempo.co/read/1002510/melanggengkan-politik-dinasti Tempo.co. (2016). Bupati Ogan Ilir Terjerat Kasus Narkoba, Siapa Penggantinya?

Retrieved February 2, 2020, from https://nasional.tempo.co/read/754358/ bupati-ogan-ilir-terjerat-kasus-narkoba-siapa-penggantinya

Viva.co, I. (2009). Syahrul Yasin Limpo Pimpin Golkar Sulsel.

Zed, M. (2008). Metode Penelitian Kepustakaan, cetakan 1. Yayasan Obor Indonesia, Jakarta.

\section{Tentang Penulis}

Fitriyah adalah dosen di Departemen Politik dan Pemerintahan, Fakultas Ilmu Sosial dan Ilmu Politik, Universitas Diponegoro. Memiliki area kajian seputar dinamika pemilu dan partai politik. 